\title{
Implementation of presidential regulation no. 76 of 2013 on public service complaint managementby the provincial government of West Sumatra
}

\author{
Yunesa Rahma ${ }^{1}$, Dasman Lanin ${ }^{2}$, Afriva Khaidir ${ }^{3}$ \\ ${ }^{123}$ Universitas Negeri Padang, Padang - Indonesia
}

\begin{abstract}
This research synthesizes the theory of applying Charles Edwards III, with 4 variables; communication, disposition, resources and organizational structure. This team principally assisted the Governor in overseeing and managing complaints relating to public services. This team has the main duty of handling public service complaints for the people in West Sumatra. Provincial government of West Sumatera has not been sufficient in implementing Presidential regulation No. 76 of 2013 on Public Service Complaint Management. In effective TP4 performance in accepting public complaints has an effect on the aims and objectives of the Presidential Regulation. TP4 West Sumatera Province more dominates the prevention performance, TP4 conducts guidance and monitoring both through working visit as well as Provincial Service Competency Assessment Team at Provincial level.
\end{abstract}

Keywords: public policy, public service, implementation, and complaints society.

\section{Introduction}

The spirit of President of Republic of Indonesia Joko Widodo in improving the quality of public services is less responded by the leaders of public service providers, particularly in the provincial/regency/city government. It can be seen in daily life, people still receive poor public services, various kinds of violations and deviations of public services are still a public complaint. If it refers to Law Number 25 of 2009 on Public Service, it can be minimized by public service providers. The organizer is required to have a public service complaints management system by appointing officials and officers, providing infrastructure and budget.

The law is confirmed through Presidential Regulation no. 76 of 2013 on the management of public service complaints. The Presidential Regulation includes; (1) the right of claimants and the obligations of the organizer; (2) means of complaint; (3) complaint management; (4) complaints management mechanism; (5) reporting, monitoring and evaluation; (6) settlement of complaints; (7) obligations and restrictions on the organizer; (8) protection of complaints; (9) performance appraisal; (10) national public service complaints management system; and (11) coaching and supervision.

When the communities do not get the service as they were expected, it should be have a forum for people to complain about the services they were received. In addition, organizer complaints handling 
provide information to improve understanding of community's right to service. Community aspiration

needs to be accommodated so that the public is encouraged to exercise control over the implementation of public services so that possible deviations can be avoided. Public service complaints management should be socialized to the public. So it will encourage the public ready to complain on the deviation of public services experienced. One of the ways is to attach or inform the management of public service complaints in strategic places.

In general, the lack of number of complaints or nil in the delivery of public services is welcomed, but it should be understood that the lack of feedback from the community and reduce opportunities for organizers to improve the quality of public services. People should be motivated if there is a problem or deviation of public service by complaining to the organizer complaint handling of public service. Based on the number of reports of complaints in the Ombudsman Representatives of West Sumatra in the implementation of public services is increased in West Sumatra, it means that the providers of public services is still weak. The data cannot yet be interpreted that public services in West Sumatra have not been implemented well, although the number of reports has not correlated with the quality of public services.

A complaint report helps public service providers to improve their service quality. The relationship between the management of the complaint of public service with the Ombudsman of the Republic of Indonesia, the reports or public complaints should be accepted by the Ombudsman should be complained (firstly) to the organizer complaint handling of the public service provider but the complaint has not been or cannot be achieved as it should be, then it can be submitted to the Ombudsman.

The Provincial Government of West Sumatra has established a Provincial Public Service Complaint Management Team (TP4) in September 2012. The team is based on Law no. 25 of 2009 on Public Service and Government Regulation no. 96 of 2013. This team principally assisted the Governor in overseeing and managing complaints relating to public services. This team has the main duty of handling public service complaints for the people in West Sumatra. In performing its main duties and functions, the Public Service Complaint Management Team is assisted by the Regional Secretariat of the Provincial Office of West Sumatra as the Secretariat of the Team, who is tasked with receiving complaints and administrative handling of the West Sumatera Provincial Public Service Complaints Management Team.

\section{Discussion}

Presidential Regulation No. 76 of 2013 on Public Service Complaints Management regulates how the public complaints handling system. The policy is a solution of the emergence of irregularities that occurred in the implementation of public services. Complaints or complaints arising from the community over the sense of incompatibility of expectations and the reality felt by the community. It thus becomes a challenge for organizers of the organization to be able to provide services in accordance with the expectations of the community. Therefore, the organizers of public organizations must have a precise and accurate system.

In handling the complaints submitted by the public in receiving a service, for the realization of quality and good satisfaction from the community. 11 indicators are required that include (1) complainants' rights and organizational obligations; (2) means of complaint; (3) complaint management; (4) complaints management mechanism; (5) reporting, monitoring and evaluation; (6) settlement of complaints; (7) obligations and restrictions on the organizer; (8) protection of 
complaints; (9) performance appraisal; (10) national public service complaints management system; and (11) coaching and supervision.

The West Sumatera Provincial Government, in implementing it, formed a Public Service Complaint Management Team (TP4) in September 2012. The team established by Governor's Decree No. 65 of 2012. The team is tasked with collecting data, analyzing and testing the truth of incoming complaints. Provide recommendations to the Governor to take the necessary steps towards data collection, analysis and testing of the truth of incoming complaints. Compile and establish complaints management codes and codes of ethics. Maintain confidentiality, the identity of witnesses and complainants. And facilitate the settlement of problems in the implementation of services.

TP4 is under the bureau of Organization of Regional Secretariat of West Sumatra Province, consisting of 16 people with various backgrounds such as academics, consultants, Minangkabau traditional leaders, religious figures, media and civil state apparatus (ASN). In addition to receiving public complaints, TP4 also conducts supervision and guidance on the Public Service Work Unit of West Sumatera Provincial Government as the Assessment Team of Prime Service Competition and Public Service Innovation at Provincial Level of West Sumatera, as Team of Drafting Provider of Public Service Provision of West Sumatera Provincial Government, and other activities in establish cooperation among other institutions. Recorded 1 community report that has been handled by TP4, report from former employee of PT. Development of West Sumatra. Following in accordance with operational standards owned by TP4, it took approximately 3 years finally the demand for money of Rp. 12.148.736, - (Twelve Million Hundred Forty Eighty Thousand Seven Hundred and Thirty Six Rupiahs) may be fulfilled by the complainant or the reported.

A series of grievance management activities conducted by the West Sumatera Provincial Public Service Complaint Management Team, which is operationally carried out by the Secretariat of the West Sumatra Provincial Organizational Bureau, in accordance with the authority held by the Decree of the Governor of West Sumatra, directly or indirectly. The complaint is through mechanism to Po Box PT. Pos Indonesia Number 02, West Sumatera Provincial Government website, Mobile Number TP4 board, complaint box that exist in every public service unit environment of West Sumatera provincial government.

The Secretariat of the Public Service Complaint Management Team records a complaint or complaint report in the organizational agenda book. Complaints and reports received will be verified and reviewed and analyzed by the secretariat in the form of a resume or letter disposition. Any complaints or reports of the public shall be responded for 14 days in accordance with the laws and regulations. The Secretariat shall see the authority or non-authority of the TP4 following up on such reports or complaints. The result of the verification is a formulation of a problem on a report or a public complaint submitted to the Chairperson of TP4 for follow-up. The Secretariat and Management of TP4 (Chairperson and Members) prepare a schedule of discussion meetings on complaints or reports. The meeting resulted in the decision of the meeting (plenary), the mechanism of the report's follow-up. If the report is the authority of TP4, then TP4 follow up the report. Subsequently, the secretariat and management (Chairperson and Member) of TP4 conducted a review or publicity visit of the community report to the reported public service work unit. The result of the visit is prepared by the secretariat of its report in the form of recommendation on suggestion or input of improvement of public service. The report was submitted by the secretariat to the Chairman of TP4 for correction and correction. So that recommendation report on suggestion and input for improvement of public service responded by Governor of West Sumatera.

The importance of complaints management of public services is not only obtained by the community as the recipient of services and bureaucracy as the service provider, but the management 
of complaints are interdependent in improving the quality of public services. For the bureaucracy of public service providers, the complaint as a benchmark and evaluation of human resources (staff), information, facilities and authority. The public also get excellent service and participate in the provision of public services more effectively and efficiently.

Charles George Edward III includes four variables, namely communication, resources, attitudes or dispositions, and bureaucratic structures. In the communication variable section, Charles Edward III also explains there are three dimensions that affect, namely transmission (spread), clarity (clarity), and consistency (consistency). Resource variables also include four aspects of human resources, facilities resources, information resources, and authority resources. Then the attitude or disposition variable is also influenced by two factors, namely the appointment of bureaucracy and incentives. Furthermore, the fourth variable of bureaucratic structure is influenced by standard operational procedure (SOP) and fragmentation.

In the implementation of the policy of Presidential Regulation concerning the management of public service complaints has been conducted through socialization since the establishment of TP4 on 27 September 2012, both to the implementer and to the service providers in the West Sumatra provincial government. However, although there are still many public service units of West Sumatera Provincial Government which do not yet have official and public service complaints mechanism.

In the implementation of the Presidential Regulation on Public Service Complaints Management on resource variables is not sufficient. This is evident in the secretariat structure of TP4 (staff), budget resources and information attached to the West Sumatra Provincial Organizational Bureau. So it can be said that the implementation of the policy has not been implemented with the maximum. This has resulted in the regulation not being effective and efficient in achieving policy goals and targets. The synthesis of Charles Edward III was criticized by James Lester through Context Theory, namely the commitment of local government and the capacity of local governments in implementing the policy.

Implementers of bureaucratic appointments that are not clear or bad affect the orders or instructions to be executed. Consequently the trust of actors' involvement also affects the two dimensions of attitude (disposition) variables. Incentives can spur the implementor to implement the policy, but accompanied by the attitude of the public manager (boss) in the technical understanding of policy implementation. The boss or the public manager must be able to adapt to both internal and external environments. Learning becomes an important part of the success or failure of the policy implemented.

In the implementation of the presidential regulation on Public Service Complaint Management, the attitude of the executing will be seen so that the policy is initially well implemented. Impression on target group is better, effect of attitude to be displayed by TP4 board and Secretariat. The existence of an organizational structure that includes the operational standards of public service complaints procedures within the West Sumatera provincial government. Public service grievance mechanisms become important variables in implementing public service complaints management policies.

The West Sumatera Provincial Public Service Complaint Management Team as the policy implementer has conducted socialization in the form of meetings, media advertisements (print and electronic) and brochures. Although in the issue of budgeting and procurement of socialization materials provided by the Organization Bureau of Regional Secretariat of West Sumatra Province. Similarly, the resources available to the Public Service Complaint Management Team are assets of the Organization Bureau such as complainee, administration staff and financial management staff.

While the authority resources owned by the Public Service Complaints Management Team of West Sumatra Province is sufficient. TP4 has entered as a recipient of public service complaints with the Ombudsman in West Sumatra Provincial Regulation No. 6 of 2015 on the Implementation of Public 
Service. In addition, the information resources owned by TP4 as the policy implementer of the Presidential Regulation in SK by the Governor of West Sumatra is very minimal.

Synthesis theory offered by Malcolm L Goggin in the form of policy implementation among Government Agencies (Intergovernmental Policy Implementation Model). In the implementation of the Presidential Regulation on Public Service Complaints Manpower at the West Sumatra Provincial Government. The commitment of the regional heads spur the implementers to implement the policy. However, the initiative emerged through the executor of the Regional Secretary through the Bureau of the Organization. As for the trigger factor of the implementation of Presidential Regulation by the Public Service Complaints Management Team of West Sumatera Province, is the Resource of authority and regional commitment through the regional head.

The authority possessed by the Public Service Complaint Management Team is mandated through Laws, Government Regulations, Presidential Regulations, Regional Regulations and Decree of the Head of Region (Governor). The authority includes to process any complaints from the public regarding the lack of services provided by the Public Service Work Unit of the West Sumatera Provincial Government. Then compile the materials in solving problems of service complained of by the community.

The subsequent authority, conveying suggestions, opinions and recommendations on quality improvement and service performance at Public Service Work Unit of West Sumatera Provincial Government to the Regional Head (West Sumatera Governor). The last authority to carry out monitoring and evaluation together with the Public Service Development Unit of the Provincial Government of West Sumatra on the improvement of the quality and performance of public services in Public Service Work Unit of West Sumatera Provincial Government.

In addition, the organizational structure is also a booster performance effectiveness TP4 West Sumatra Province. The collective management of TP4 is collegial with various levels of education and scope. Becoming a proponent of TP4 implements the Presidential Regulation and the mandate of the Governor of West Sumatra in managing public service complaints. Seven core managers consist of Chair, Vice Chair, Secretary and Members with various backgrounds covering from YLKI West Sumatra, mass media, provincial bureaucracy, West Sumatran University of Indonesia, West Sumatra LKAAM and Andalas University academic.

While the inhibiting factor of the implementation of the Presidential Regulation concerning the management of public service complaints is the resources of human resources, information and facilities (infrastructure and budget). The incorporation of TP4 within the Organizational Bureau of the Province of West Sumatra hinders the implementation of the policy. The information resources owned by TP4 are still lacking, both information on policy implementation from central government and feedback in the form of information obtained from the target group (bureaucracy and society). While the resources of facilities, especially the budget for equipment such as office equipment is still attached to the Bureau of the Organization. This inhibits TP4 in the implementation of Presidential Regulation No. 76 of 2013 on Public Service Complaint Management.

The ineffectiveness of TP4 West Sumatera's performance in managing public service complaints is helped by the presence of Ombudsman of West Sumatra. Supposedly the complaint to be submitted to TP4 West Sumatra Province is quite easy and open by using various media. The ease of public access is reflected by the number of managed reports and how the report is delivered. Reports related to community dissatisfaction with services provided by service work units within West Sumatera provincial government. 


\section{Conclusions}

Public service complaints management mechanism conducted by TP4 West Sumatera Province is not yet adequate from the aspect of policy implementation. This can be seen from the absence of special rules such as guidelines, technical guidance, related to the management of complaints on the job description of complaints managers..

Implementation of Presidential Regulation No. 76 of 2013 on Public Service Complaint Management in West Sumatera Province has not been generally implemented well. This is evident from the results obtained that the implementation of the activities or operations of the Public Service Complaints Management Team that depends on the Organization Bureau of West Sumatra Regional Secretariat. So the goals and objectives of the Presidential Regulation have not gone well.

The performance effectiveness of Public Service Complaint Management Team by West Sumatera Province is influenced by two factors, namely trigger factor and inhibiting factor. The trigger factor is the authority resources, the commitment of the regional head and the organizational structure in implementing it. While the inhibiting factors of resources, especially human resources (staff), information and facilities (infrastructure and budget).

Based on the results of the research, the researcher gives input on the suggestion, as follows:

1. For the Provincial Government of West Sumatra further increase the seriousness in the management of complaints of public services in the Province of West Sumatra. The government needs to strengthen TP4 as an independent and sustainable institutional. So that the existence of $\mathrm{TP} 4$ can be known by the targets group both the bureaucracy within the provincial government and the people of West Sumatra. Or otherwise, the West Sumatera Provincial Public Service Complaint Management Team was dissolved, due to ineffective performance in managing public complaints within the West Sumatera provincial government.

2. For the Board of Public Service Complaints Management Team, to be more active in cooperation with the Ministry/Agency/Agency in the socialization of the main duty and authority. So the impact and benefits of TP4 in improving public services in West Sumatra can be effective and efficient.

3. For the staff of the Public Service Work Unit within the Provincial Government of West Sumatra to follow up on policies that have been established by both central and local government policies, by providing complaints mechanisms, procedures and following up on public service complaints from the public.

\section{References}

Abdul Wahab, Solichin. (2012). Analisis kebijaksanaan dari Formulasi ke Implementasi Kebijaksanaan Negara. Jakarta: Bumi Aksara.

Agus Purwanto, Erwan dan Dyah Ratih Sulistyastuti. (2010). Implementasi Kebijakan Publik (Konsep dan Aplikasinya di Indonesia). Yogyakarta: Gava Media.

A.G. Subarsono. (2008). Analisis Kebijakan Publik. Yogyakarta: Pustaka Pelajar.

Burhan Bungin. (2012). Metode Penelitian Kualitatif (Aktualisasi Metodologis Ke Arah Ragam Varian Kontemporer). Jakarta: PT Raja Grafindo Persada.

Dunn, W. N. (2000). Pengantar Analisis Kebijakan Publik. Yogyakarta: Gajah Mada University.

Denhardt, Janet V. and Denhardt, Robert B., (2007). The New Public Service, Serving Not Steering, Expanded Edition, Armonk, New York, London, England: M.E.Sharpe.

Edward III, George C. (1980). Implementing Public Policy. Washington DC : Congresional Quarterly Press. 
Grindle, Merilee. (1980). Politics and Policy Implementation in Third World. New Jersey: Princenton University Press.

Gorton, Michael dkk. (2005). Guide to Complaint Handling in Health Care Services. William Troedel \& Co Pty Ltd.

Hadi, Anwar. (2000). Sistem Manajemen Mutu Laboratorium. Jakarta: Gramedia

Kurniawan, Agung. (2005). Transformasi Pelayanan Publik. Yogyakarta: Pembaruan

Lanin, Dasman. (2015). Teori dan Praktik Manajeman Publik. Jurusan Ilmu Administrasi Negara UNP

Maleong, Lexi J. (2010). Metode Penelitian Kualitatif. Bandung: PT Remaja Rosdakarya.

Narbuko, Cholid, Drs dan Drs. H. Abu Achmadi. (1997). Metodologi Penelitian. Jakarta: Bumi Aksara.

Patton, Michael Quinn. (2006). Metode Evaluasi Kualitatif. Yogyakarta: Pustaka Pelajar.

Prawirosentono, Suyadi. (1999). Kebijakan Kinerja Karyawan. Yogyakarta: BPFE

Reza Banakar and Max Travers. (2005). Theory and Method in Socio-Legal Research, Onati: Hart Publishing Oxford and Portland Oregon.

Ritzer, George dan Douglas J. Goodman. (2007). Teori Sosiologi Modern. Edisi ke-6. Jakarta: Kencana.

Sangarimbun, Masri dan Sofian Effendi. (1995). Metode Penelitian Survai. Jakarta: LP3ES.

Suradinata, Ermaya, (1998), Manajemen Pemerintahan dan Otonomi Daerah. Bandung:Ramadan.

Solihin, Abd Wahab, (2004). Analisis Kebijakan I, Haji Mas Agung. Jakarta.

Sondang P. Siagian. (2010). Manajemen Sumber Daya Manusia, Bumi Aksara. Jakarta

Subarsono, AG. (2011). Analisis kebijakan Publik: Konsep. Teori dan Aplikasi. Yogyakarta: Pustaka Pelajar.

Smith, Brian C. (2012). Decentralization: The Territorial Dimension of The State. Jakarta: Masyarakat Pemerintahan Indonesia

Widodo, Joko, (2010). Analisis Kebijakan Publik: Konsep dan Aplikasi Analisis Proses Kebijakan Publik. Malang: Bayumedia Publishing.

Winarno, Budi. (2005). Teori dan Proses Kebijakan Publik. Yogyakarta:Media Pressindo (Anggota IKAPI). 